\title{
Trace metal enrichment in sugarcane soils due to the long-term application of fertilisers, North Queensland, Australia: geochemical and $\mathrm{Pb}, \mathrm{Sr}$, and $\mathrm{U}$ isotopic compositions
}

\author{
Bernd G. Lottermoser \\ School of Earth and Environmental Sciences, James Cook University, Townsville, Qld 4811, Australia. \\ Email: Bernd.Lottermoser@jcu.edu.au
}

\begin{abstract}
This study aimed to determine whether $>80$ years of fertiliser application has led to recognisable changes in the trace metal $(\mathrm{Cd}, \mathrm{Cu}, \mathrm{Mo}, \mathrm{Ni}, \mathrm{Pb}, \mathrm{Sr}, \mathrm{Th}, \mathrm{U}, \mathrm{Zn})$ chemistry of topsoils $(0-0.10 \mathrm{~m})$ from sugarcane land, northern Queensland, Australia. The metal concentrations of commercial nitrogen $(\mathrm{N})$ and potassium (K) fertilisers currently used in northern Queensland were generally lower than those of phosphate fertilisers and fertiliser blends. Composite topsoil samples (0-0.10 m depth) taken from canelands had higher median $\mathrm{Cd}, \mathrm{Mo}, \mathrm{Pb}, \mathrm{Sr}$, Th, $\mathrm{U}$, and $\mathrm{Zn}$ concentrations than topsoils from forested areas of the catchment. Niobium, Ta, and Ti were confirmed as refractory immobile elements and used as reference elements for the evaluation of trace metal enrichments. Bivariate plots of trace metal/immobile element ratios verified that $\mathrm{Cd}, \mathrm{Mo}, \mathrm{Pb}, \mathrm{Sr}, \mathrm{Th}, \mathrm{U}$, and $\mathrm{Zn}$ are enriched in sugarcane soils compared with background forest soils. Isotopic ratios for $\mathrm{Pb}, \mathrm{Sr}$, and $\mathrm{U}$ highlight that fertilisers, cane soils, and forest soils have isotopically distinct compositions. Phosphate fertilisers currently used in the agricultural industry possess the most radiogenic ${ }^{87} \mathrm{Sr} /{ }^{86} \mathrm{Sr},{ }^{234} \mathrm{U} /{ }^{238} \mathrm{U}$, ${ }^{207} \mathrm{~Pb} /{ }^{206} \mathrm{~Pb}$, and ${ }^{208} \mathrm{~Pb} /{ }^{206} \mathrm{~Pb}$ ratios. Background forest soils have the highest ${ }^{87} \mathrm{Sr} /{ }^{86} \mathrm{Sr},{ }^{207} \mathrm{~Pb} /{ }^{206} \mathrm{~Pb}$, and ${ }^{208} \mathrm{~Pb} /{ }^{206} \mathrm{~Pb}$ and lowest ${ }^{234} \mathrm{U} /{ }^{238} \mathrm{U}$ ratios. By contrast, cane soils exhibit ${ }^{207} \mathrm{~Pb} /{ }^{206} \mathrm{~Pb}$ and ${ }^{208} \mathrm{~Pb} /{ }^{206} \mathrm{~Pb}$ ratios that appear on a mixing line between the isotopically distinct background soils and phosphate fertilisers. Also, cane soils possess ${ }^{234} \mathrm{U} /{ }^{238} \mathrm{U}$ ratios similar to phosphate fertilisers. Thus, the application of phosphate fertilisers to canelands has resulted in higher Cd, Mo, $\mathrm{Pb}, \mathrm{Sr}$, Th, $\mathrm{U}$, and $\mathrm{Zn}$ concentrations and more radiogenic $\mathrm{Pb}, \mathrm{Sr}$, and $\mathrm{U}$ isotope ratios in cane soils. Trace metal ratios and the $\mathrm{Pb}, \mathrm{Sr}$, and $\mathrm{U}$ isotopic composition of topsoils and fertilisers are useful tools to recognise fertiliser-derived trace metals in agricultural landscapes.
\end{abstract}

Additional keywords: fertiliser, trace metals, $\mathrm{Pb}$ isotopes, $\mathrm{Sr}$ isotopes, $\mathrm{U}$ isotopes, cane soils.

\section{Introduction}

The agricultural industry increasingly relies on manufactured fertilisers to provide nutrients to crops. Such practices cause the annual transfer of several hundred tonnes of metals and metalloids into soils globally because metals and metalloids are present as impurities and active compounds in agricultural chemicals (Nriagu and Pacyna 1988). The main source of fertiliser-derived contaminants in soils is phosphatic fertilisers, primarily due to impurities in the phosphate rock used for fertiliser manufacture (Williams and David 1973, 1976; Raven and Loeppert 1997; McBride and Spiers 2001). Much of the previous research has focused on the $\mathrm{Cd}$ content of fertilisers and their impact on agricultural soils (e.g. Williams and David 1973, 1976; McLaughlin et al. 2000; Taylor 1997). However, Molloy et al. (2005) concluded that other fertiliserderived inorganic contaminants (specifically As, B, Cr, $\mathrm{Cu}, \mathrm{F}, \mathrm{Hg}, \mathrm{Ni}, \mathrm{Pb}, \mathrm{Se}$, and $\mathrm{Zn}$ ) may also pose a particular environmental risk of accumulating in, or impacting on, soils, crops, and aquifers.

Topsoils used for sugarcane production in central and southern Queensland are known to possess elevated $\mathrm{Cd}$ and
Hg values compared with non-cane soils (Rayment et al. 1997). Such element enrichments have been assigned to the use of phosphate fertilisers and $\mathrm{Hg}$ fungicides. By comparison, the impact of fertilisers on the concentrations of other trace metals in cane soils remains relatively unexplored. This paper reports on metal distributions $(\mathrm{Cd}, \mathrm{Cu}, \mathrm{Mo}, \mathrm{Nb}, \mathrm{Ni}, \mathrm{Pb}, \mathrm{Sr}, \mathrm{Ta}, \mathrm{Th}, \mathrm{Ti}$, $\mathrm{U}, \mathrm{Zn}$ ) in cane soils of the Saltwater Creek catchment, North Queensland, Australia. Emphasis is placed in this work on trace element ratios and isotope studies as they have been used to identify fertiliser-derived trace metals in sugarcane lands.

\section{Saltwater Creek catchment Physiography and climate}

The Saltwater Creek catchment is situated in the wet tropics region of North Queensland, centred on $16^{\circ} 24^{\prime} \mathrm{S}, 145^{\circ} 23^{\prime} \mathrm{E}$, $\sim 60 \mathrm{~km}$ north of Cairns (Fig. 1). The Saltwater Creek catchment covers an area of $\sim 139 \mathrm{~km}^{2}$. The catchment incorporates 2 prominent physiographic entities: the PalmerHodgkinson Uplands of deeply dissected, rugged mountainous country to the west, and the narrow Coastal Plain with flat to 


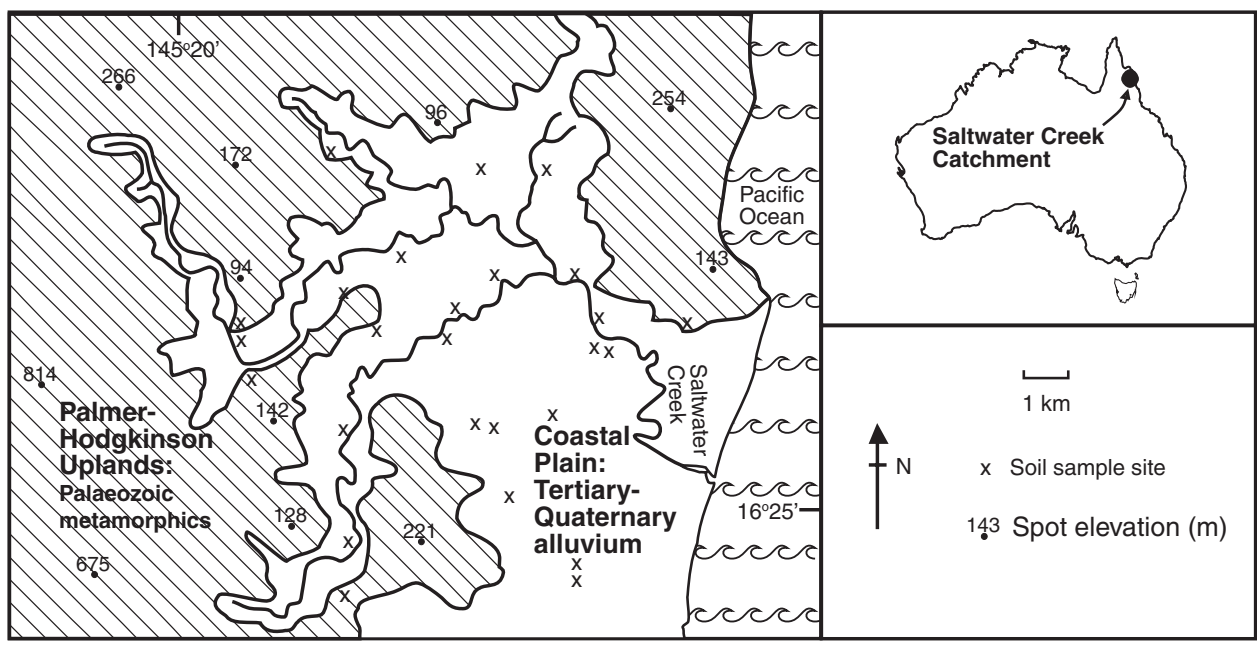

Fig. 1. Plan of the Saltwater Creek catchment, North Queensland. Location of sample sites for forest and cane soils, spot elevation, and physiographic entities are indicated.

gently undulating lowlands to the east (Fig. 1). Altitudes in the catchment range from 0 to $1300 \mathrm{~m}$. The north-trending Great Dividing Range, a continental drainage divide ( 1000-1300 m), is located $\sim 10 \mathrm{~km}$ west.

The region has a tropical monsoonal climate, with distinct wet and dry seasons and $80 \%$ of annual rainfall falling between November and April. The average annual rainfall in the region has been estimated at $2003 \mathrm{~mm}$ (Port Douglas weather station, $10 \mathrm{~km}$ south-east of catchment) (Bureau of Meteorology 2008). The relatively wet conditions are directly influenced by the proximity of the up to 1300 -m-high escarpment to the west. The eastern margin of the rugged Great Dividing Range descends abruptly to the coastal plain. The plain is drained by Saltwater Creek, associated tributaries, and man-made drains; drainage waters enter the Great Barrier Reef lagoon of the Pacific Ocean (Fig. 1).

\section{Geology, soils, and landuse}

The upper Saltwater Creek catchment (i.e. the PalmerHodgkinson Uplands) consists of large tracts of early Permian Mt Carbine Granite and Hodgkinson Formation, a regionally extensive Devonian succession comprising turbiditic metasedimentary rocks (Bultitude et al. 1996). The lower Saltwater Creek catchment (i.e. the Coastal Plain), including the study area, consists of partly consolidated TertiaryQuaternary colluvial, alluvial, and coastal dune deposits and turbiditic metasedimentary rocks in the hills and slopes.

The upper catchment is covered with vine forest, and large areas of the forested lowland country have been cleared for agricultural production. The coastal lowlands are mainly utilised for sugarcane and to a lesser degree for cattle grazing and smallscale horticulture. Much of the agricultural land is found on Tertiary-Quaternary poorly sorted alluvial sands that derived from the weathering and erosion of the surrounding metamorphic rocks (Murtha 1989).

Soils used for agriculture on the coastal lowlands are largely poorly and well-drained soils formed on alluvium, and topsoils vary in texture from light-medium clays to sandy-silty loams
(Murtha 1989). Soils in the adjacent uncleared rainforest are dominantly red podzolic clay loams. The soils are naturally deficient in the major elements $(\mathrm{N}, \mathrm{P}, \mathrm{K})$. Addition of these nutrients has been necessary for large-scale crop production in the form of fertilisers, particularly sugarcane since the 1920s (Pulsford 1993). In the Saltwater Creek catchment, N rates on cane were $<100 \mathrm{~kg} / \mathrm{ha}$ until the mid-1950s (Pulsford 1993). Rates increased during the 1960 s and 1970 s, with application of $\sim 170 \mathrm{~kg} \mathrm{~N} / \mathrm{ha}$ on plant cane and $180 \mathrm{~kg} \mathrm{~N} / \mathrm{ha}$ on ratoons. Usage of $\mathrm{P}$ was at a low level, $<10 \mathrm{t}$ annually, prior to 1950 (Pulsford 1993). During the 1960s and 1970s, there has been an increase, generally in line with the area of sugarcane, reaching $\sim 120$ t $\mathrm{P}$ in 1981 , with stability or a slight decrease in recent years. Usage in plant cane is $\sim 60 \mathrm{kgP} / \mathrm{ha}$, about 3 times the rate used on ratoons. Some ratoons may not be fertilised with $\mathrm{P}$ every year, so that the average rate for the whole cane area grown is $18 \mathrm{~kg} \mathrm{P} /$ ha (Pulsford 1993).

\section{Materials and methods}

A suite of dry commercial fertiliser samples (12 different products including $\mathrm{N}, \mathrm{P}, \mathrm{K}$, and blended fertilisers) was obtained from the Queensland Department of Natural Resources and Water, Mareeba. This suite is representative of fertilisers currently being used in the agricultural industry of North Queensland. In addition, bagged phosphate fertilisers were purchased from a local supplier in Mossman $(6 \mathrm{~km}$ south of the catchment). Several hundred grams of dry commercial phosphate fertilisers (3 different products including superphosphate, diammonium phosphate, and N-P-K fertiliser blend) used in the cane industry were taken from the bags using a plastic scoop. Representative subsamples were ground to powders using a chrome-steel ring mill, and a 2-g sample was dissolved in $30 \mathrm{~mL}$ aqua regia for $20 \mathrm{~min}$ at room temperature. Sample solutions were subsequently analysed by inductively coupled plasma mass spectrometry (ICPMS) for Ag, $\mathrm{As}, \mathrm{Cd}, \mathrm{Cu}, \mathrm{Hg}, \mathrm{Mo}, \mathrm{Ni}, \mathrm{Pb}, \mathrm{Sb}, \mathrm{Sr}, \mathrm{Th}, \mathrm{Tl}, \mathrm{U}$, and $\mathrm{Zn}$ at the James Cook University Advanced Analytical Centre (JCU AAC, Townsville). 
In all, 27 soil sampling sites were chosen in the lower Saltwater Creek catchment to give a sampling grid of $\sim 1$ sample per $4 \mathrm{~km}^{2}$. Soil samples were taken from 2 environments: (1) sugarcane land $(n=19)$, and (2) forested areas that have never been cleared for agricultural production $(n=8)$. Topsoil samples were taken using a plastic trowel (depth $0-0.10 \mathrm{~m} ; \sim 1 \mathrm{~kg})$. Each sample consisted of 5-10 subsamples taken from a $4-\mathrm{m}^{2}$ area, and these subsamples were composited to improve site representativeness.

Soil sample powders were fused with lithium metaborate and dissolved beads analysed for their total trace metal (Ag, Cu, Mo, Ni, Pb, Sr, Ta, Th, Tl, U, Zn, Zr) content by ICPMS at Australian Laboratory Services (ALS, Brisbane). Sample powers were also dissolved in strong acids (HF, $\mathrm{HNO}_{3}, \mathrm{HClO}_{4}$ ) and analysed for $\mathrm{Cd}$ by ICPMS at ALS. In addition, representative aliquots of soil samples were analysed by X-ray fluorescence for $\mathrm{Ti}$ and $\mathrm{Nb}$ (JCU AAC). Quality control/assurance of the data was obtained using analyses of sample replicates, blanks, and international reference standard GXR-3. The obtained GXR-3 concentrations corresponded closely to the published compilation concentrations with the exception of $\mathrm{Zr}$ concentrations, most likely due to incomplete digestion of zircon phases. Standard deviation values for the repeated analysis of the reference material were $<5 \%$ of the mean concentrations for each element, indicating high accuracy of the results.

The $\mathrm{Pb}$ isotope ratios in topsoils $(n=27)$ and selected phosphate fertilisers $(n=5)$ were evaluated using a $1 \mathrm{M} \mathrm{HCl}$ partial extraction technique. The extraction procedure was chosen to yield dilute-acid extractable $\mathrm{Pb}$ isotope ratios because: $(a)$ the use of $1 \mathrm{M} \mathrm{HCl}$ soluble metal concentrations as an estimate of the maximum bioavailable fraction has been recommended by the Australian and New Zealand Environment and Conservation Council (ANZECC 2000); (b) fertilisers are readily soluble in soil environments and hence a mild acid leachate was applied to target the soluble $\mathrm{Pb}$ isotope fraction in the investigated soils; and (c) since a considerable fraction of the total $\mathrm{Pb}$ is likely tightly bound in mineral particles and a dilute acid extraction will not remove the mineralised fractions, analysis of the dilute-acid extractable $\mathrm{Pb}$ isotope ratios would provide more appropriate data for recognising fertiliser impacts on soils. Approximately $0.5 \mathrm{~g}$ of sample was extracted in $5 \mathrm{~mL}$ $1 \mathrm{M} \mathrm{HCl}$ at $30^{\circ} \mathrm{C}$ for $1 \mathrm{~h}$. Lead isotope analyses of the leachates were carried out using ICPMS techniques (quadropole ICPMS ELAN 6000) at Charles Darwin University (Darwin). Quality control/assurance of the partial extraction data was applied using subsample duplicates, digest blanks, and geochemical reference materials (AGAL-12, IAEA-Soil 7). The determined $\mathrm{Pb}$ isotope ratios carried precisions on $\mathrm{XXX} / 206$ (where $\mathrm{XXX}=207$ and 208) ratios of $\sim 0.5 \%$. The $\mathrm{Pb}$ isotope ratios ${ }^{207} \mathrm{~Pb} /{ }^{206} \mathrm{~Pb}$ and ${ }^{208} \mathrm{~Pb} /{ }^{206} \mathrm{~Pb}$ were measured by normalising to the NISTSRM981 Standard Reference Material $\left({ }^{207} \mathrm{~Pb} /{ }^{206} \mathrm{~Pb}=0.91464\right.$ and $\left.{ }^{208} \mathrm{~Pb} /{ }^{206} \mathrm{~Pb}=2.1681\right)$.

Exploratory $\mathrm{Sr}$ isotope $\left({ }^{87} \mathrm{Sr} /{ }^{86} \mathrm{Sr}\right)$ analyses were conducted on $1 \mathrm{M} \mathrm{HCl}$ leachates of selected topsoils $(n=7)$ and phosphate fertilisers $(n=3)$. Approximately $0.5 \mathrm{~g}$ of sample was leached in $5 \mathrm{~mL} 1 \mathrm{M} \mathrm{HCl}$ at $20^{\circ} \mathrm{C}$ for $1 \mathrm{~h}$. Strontium in the samples was purified using nitric acid and column chromatography with an Eichrom Technologies cation exchange resin. ${ }^{87} \mathrm{Sr} /{ }^{86} \mathrm{Sr}$ values were measured on a VG Sector 54 Thermal Ionisation Mass Spectrometer at CSIRO Petroleum Resources (Sydney, Australia). These analyses carried precisions of $10-18 \mathrm{ppm}$

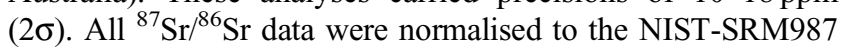
value of 0.710240 (Hart et al. 2004).

Exploratory $\mathrm{U}$ isotope $\left({ }^{234} \mathrm{U} /{ }^{238} \mathrm{U}\right)$ analyses were conducted on selected topsoils $(n=7)$ and phosphate fertilisers $(n=2)$ at the Institute for Environmental Research (ANSTO, Sydney). Approximately $5 \mathrm{~g}$ of each sample was brought into complete dissolution using repeated acid attacks with $\mathrm{HF}, \mathrm{H}_{2} \mathrm{O}_{2}, \mathrm{HClO}_{4}$, $\mathrm{HNO}_{3}$, and $\mathrm{HCl}$. The solution was heated to dryness and the residue dissolved in $6 \mathrm{M} \mathrm{HCl}$. Uranium was co-precipitated with $\mathrm{Fe}, \mathrm{Fe}$ was extracted with ether, and $\mathrm{U}$ was separated by ion exchange resins from other elements. Uranium was electrodeposited on a stainless-steel disk. The $U$ isotope composition $\left({ }^{234} \mathrm{U} /{ }^{238} \mathrm{U}\right)$ was determined on each stainless steel disk using $\alpha$ spectrometry and counting for 1-5 days depending of the activities of the radionuclides. The activity ratio (AR) was calculated from the activities of ${ }^{234} \mathrm{U}$ and ${ }^{238} \mathrm{U}$. The analyses carried precisions of $\sim 300-500 \mathrm{ppm}$.

\section{Results}

\section{Fertilisers}

The Ag, As, Cd, Cu, Hg, Mo, Ni, Pb, Sb, Sr, Th, Tl, U, and Zn contents of $\mathrm{K}$ and $\mathrm{N}$ fertilisers are generally low, with the fertilisers having total $\mathrm{As}, \mathrm{Cd}, \mathrm{Cu}, \mathrm{Ni}, \mathrm{Pb}, \mathrm{Tl}, \mathrm{U}$, and $\mathrm{Zn}$ below detection limits (Table 1). By contrast, the phosphate fertilisers and the trace metal enriched phosphate blends contained detectable concentrations of $\mathrm{Ag}, \mathrm{As}, \mathrm{Cd}, \mathrm{Cu}, \mathrm{Hg}$, $\mathrm{Mo}, \mathrm{Ni}, \mathrm{Pb}, \mathrm{Sb}, \mathrm{Sr}$, Th, Tl, U, and $\mathrm{Zn}$ (Table 1). Such a relative metal enrichment of phosphate fertilisers and trace metal enriched phosphate blends is commensurate with the known metal chemistry of commercial fertilisers (McBride and Spiers 2001). The isotope analyses reveal that the phosphate fertilisers have the lowest and most radiogenic ${ }^{87} \mathrm{Sr} /{ }^{86} \mathrm{Sr},{ }^{207} \mathrm{~Pb} /{ }^{206} \mathrm{~Pb}$, and ${ }^{208} \mathrm{~Pb} /{ }^{206} \mathrm{~Pb}$ ratios of all analysed samples (Tables 1,2 ). Furthermore, the ${ }^{234} \mathrm{U} /{ }^{238} \mathrm{U}$ ratio of phosphate fertilisers is near unity, reflecting an abundance of radiogenic ${ }^{234} \mathrm{U}$. The distinctly radiogenic $\mathrm{Sr}$ and $\mathrm{Pb}$ isotope signature of phosphate fertilisers is likely caused by their elevated $\mathrm{Rb}$ and $\mathrm{U}$ contents.

\section{Topsoil chemistry}

A summary of the trace metal chemistry of topsoils from the Saltwater Creek catchment is given in Table 2. A comparison of trace metal concentrations within the cane and forest soils has been based on: $(a)$ the mean metal concentration plus 1 standard deviation; and $(b)$ the median metal value. The mean $\mathrm{Cd}, \mathrm{Mo}$, $\mathrm{Pb}, \mathrm{Sr}$, Th, U, and $\mathrm{Zn}$ content plus 1 standard deviation and the median $\mathrm{Cd}, \mathrm{Mo}, \mathrm{Pb}, \mathrm{Sr}$, Th, $\mathrm{U}$, and $\mathrm{Zn}$ value are distinctly higher in the cane soils than in the forest soils (Table 2).

The level of metal accumulation in soils is largely influenced by underlying parent materials, soil type, and anthropogenic additions. Thus, published total metal concentrations of soils vary greatly, even on a local scale, and elemental concentration data on their own can be insensitive indicators of anthropogenic influences in heterogeneous environments such as soils. A more reliable determination of natural levels of metals is best done on the basis of immobile elements and trace element ratios. 


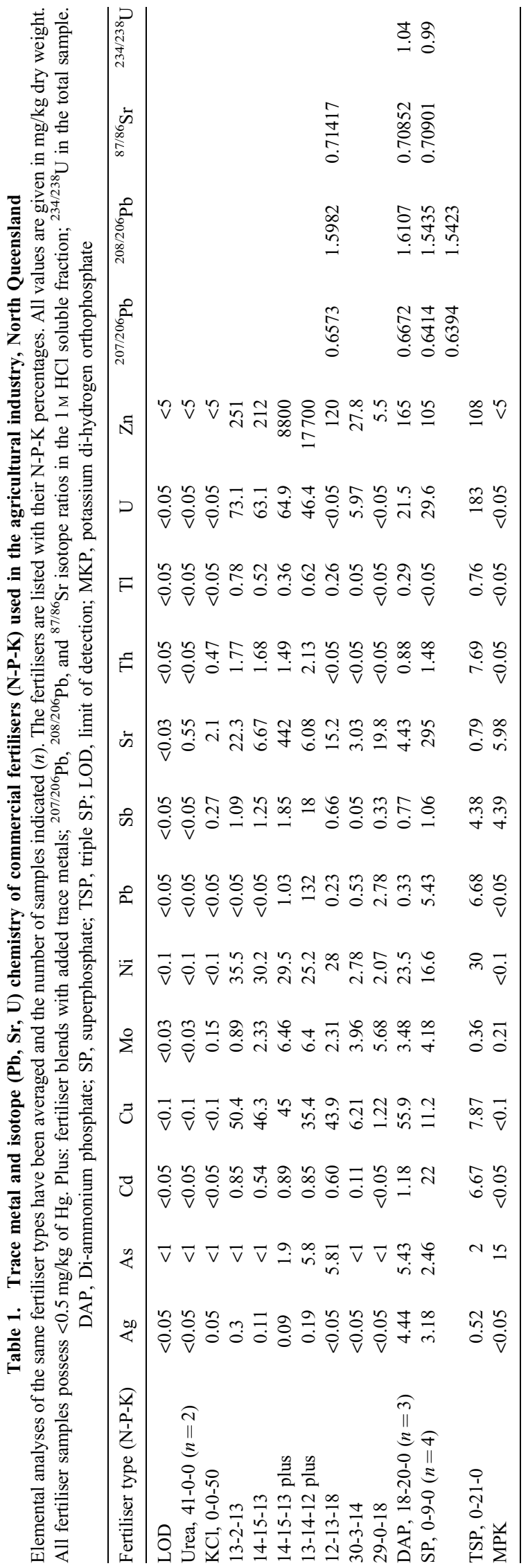


Refractory trace elements in soils exhibit constant element ratios even when their total soil concentrations become enriched or depleted during pedogenesis. In strongly weathered tropical soils, $\mathrm{Nb}$, Ta, and $\mathrm{Ti}$ have been established as immobile elements, displaying a restricted range of immobile element ratios (e.g. Kurtz et al. 2000; Meijer and Buurman 2003; Buurman et al. 2004). The recognition of immobile elements allows the determination of gains and losses of other elements, which can be established relative to the immobile elements. Consequently, metal-contaminated soils tend to have higher metal/immobile element ratios, reflecting the anthropogenic addition of metals. Such a normalisation procedure has the potential to separate natural background from contaminated soil populations.

In the soils studied, the $\mathrm{Ti}, \mathrm{Nb}$, and $\mathrm{Ta}$ concentrations display strong positive correlations $(\mathrm{Ti}-\mathrm{Nb}+0.8, \mathrm{Ti}-\mathrm{Ta}+0.65, \mathrm{Nb}-\mathrm{Ta}$ $+0.78)$, and both the cane and forest soils display a narrow range of $\mathrm{Ta} / \mathrm{Nb}$ and $\mathrm{Nb} / \mathrm{Ti}$ ratios (Fig. $2 a, b$ ). The fact that these ratios

Table 2. Trace metal and isotope $(\mathrm{Pb}, \mathrm{Sr}, \mathrm{U})$ chemistry of cane and forest soils

Elemental values are given in $\mathrm{mg} / \mathrm{kg}$ dry weight. All samples possess $<1 \mathrm{mg} / \mathrm{kg} \mathrm{Ag}$ and $<0.5 \mathrm{mg} / \mathrm{kg} \mathrm{Tl}$. $n$, No. of samples. ${ }^{207 / 206} \mathrm{~Pb},{ }^{208 / 206} \mathrm{~Pb}$, and ${ }^{87 / 86} \mathrm{Sr}$ isotope ratios in the $1 \mathrm{~m} \mathrm{HCl}$ soluble fraction; ${ }^{234 / 238} \mathrm{U}$ in the total sample; LOD, limit of detection

\begin{tabular}{|c|c|c|c|c|c|c|}
\hline & LOD & Min. & Max. & Mean & Median & s.d. \\
\hline \multicolumn{7}{|c|}{ Forest soils $(n=8)$} \\
\hline $\mathrm{Cd}$ & 0.02 & $<0.02$ & 0.04 & $<0.02$ & $<0.02$ & 0.01 \\
\hline $\mathrm{Cu}$ & 5 & 8 & 21 & 12.6 & 11.5 & 4.34 \\
\hline Mo & 2 & $<2$ & 6 & 2.5 & 2 & 1.41 \\
\hline $\mathrm{Nb}$ & 2 & 9 & 26 & 16.4 & 15 & 7.11 \\
\hline $\mathrm{Ni}$ & 5 & $<5$ & 24 & 10.3 & 8.5 & 6.71 \\
\hline $\mathrm{Pb}$ & 5 & 8 & 25 & 14.9 & 13 & 5.27 \\
\hline $\mathrm{Sr}$ & 0.1 & 6.4 & 36.7 & 18.1 & 16.9 & 8.64 \\
\hline $\mathrm{Ta}$ & 0.5 & $<0.5$ & 1.4 & 0.83 & 0.85 & 0.31 \\
\hline Th & 1 & 6 & 13 & 9.5 & 9.5 & 2.32 \\
\hline $\mathrm{Ti}$ & 5 & 2690 & 6920 & 4210 & 4073 & 1417 \\
\hline $\mathrm{U}$ & 0.5 & 1.3 & 2.3 & 1.83 & 2.0 & 0.45 \\
\hline $\mathrm{Zn}$ & 5 & 28 & 41 & 34 & 33 & 4.50 \\
\hline${ }^{207 / 206} \mathrm{~Pb}(n=8)$ & & 0.8300 & 0.8629 & 0.8427 & 0.8380 & 0.0120 \\
\hline${ }^{208 / 206} \mathrm{~Pb}(n=8)$ & & 2.0785 & 2.1139 & 2.0980 & 2.1007 & 0.0138 \\
\hline${ }^{87 / 86} \mathrm{Sr}(n=3)$ & & 0.7181 & 0.7208 & 0.7191 & & \\
\hline${ }^{234 / 238} \mathrm{U}(n=4)$ & & 0.83 & 1.00 & 0.92 & & \\
\hline \multicolumn{7}{|c|}{ Cane soils $(n=19)$} \\
\hline $\mathrm{Cd}$ & 0.02 & 0.03 & 0.15 & 0.07 & 0.06 & 0.04 \\
\hline $\mathrm{Cu}$ & 5 & 5 & 21 & 10.4 & 9 & 3.71 \\
\hline Mo & 2 & $<2$ & 36 & 6.16 & 3 & 8.29 \\
\hline $\mathrm{Nb}$ & 2 & 8 & 22 & 14.5 & 15 & 4.17 \\
\hline $\mathrm{Ni}$ & 5 & $<5$ & 21 & 9.11 & 7 & 5.21 \\
\hline $\mathrm{Pb}$ & 5 & 10 & 37 & 25.3 & 28 & 8.79 \\
\hline $\mathrm{Sr}$ & 0.1 & 10.5 & 44.7 & 25.7 & 29.1 & 9.97 \\
\hline Тa & 0.5 & $<0.5$ & 1.4 & 0.91 & 0.9 & 0.28 \\
\hline Th & 1 & 6 & 39 & 21 & 22 & 10.5 \\
\hline $\mathrm{Ti}$ & 5 & 2190 & 5130 & 3820 & 3860 & 776 \\
\hline $\mathrm{U}$ & 0.5 & 1.3 & 6.3 & 3.7 & 3.3 & 1.37 \\
\hline $\mathrm{Zn}$ & 5 & 31 & 75 & 49.5 & 46 & 13.3 \\
\hline${ }^{207 / 206} \mathrm{~Pb}(n=19)$ & & 0.8192 & 0.8498 & 0.8305 & 0.8307 & 0.0069 \\
\hline${ }^{208 / 206} \mathrm{~Pb}(n=19)$ & & 2.0540 & 2.1098 & 2.0739 & 2.0716 & 0.0134 \\
\hline${ }^{87 / 86} \mathrm{Sr}(n=4)$ & & 0.7112 & 0.7286 & 0.7171 & & \\
\hline${ }^{234 / 238} \mathrm{U}(n=3)$ & & 1.00 & 1.03 & 1.01 & & \\
\hline
\end{tabular}

remain constant in forest and cane soils implies that $\mathrm{Nb}, \mathrm{Ta}$, and Ti behaved as immobile elements during pedogenesis and that the forest and cane soils derived from the same geological bedrock (i.e. metasediments exposed in the surrounding hills). The alternative explanation that the 3 elements were lost at the same rate at all sites is perceived as unlikely. The immobile element ratio approach has been used to determine the addition of trace metals to the studied soils. Niobium and $\mathrm{Ti}$ were considered as immobile elements, although normalising to $\mathrm{Ta}$ instead of $\mathrm{Nb}$ produces nearly identical results. The cane soils display distinctly higher $\mathrm{Cd} / \mathrm{Nb}, \mathrm{Mo} / \mathrm{Nb}, \mathrm{Pb} / \mathrm{Nb}, \mathrm{Sr} / \mathrm{Ti}, \mathrm{Th} / \mathrm{Nb}$, $\mathrm{U} / \mathrm{Nb}, \mathrm{U} / \mathrm{Ti}$, and $\mathrm{Zn} / \mathrm{Ti}$ ratios than the forest soils (Fig. $3 a-e$ ). By contrast, forest and cane soils display a similar range of $\mathrm{Cu} / \mathrm{Nb}$ and $\mathrm{Ni} / \mathrm{Ti}$ ratios (Fig. 4). Thus, the $\mathrm{Cu}$ and $\mathrm{Ni}$ concentrations of cane soils do not appear to be enriched and these element contents represent natural local background values. By contrast, $\mathrm{Cd}, \mathrm{Mo}, \mathrm{Pb}, \mathrm{Sr}$, Th, $\mathrm{U}$, and $\mathrm{Zn}$ are variably enriched
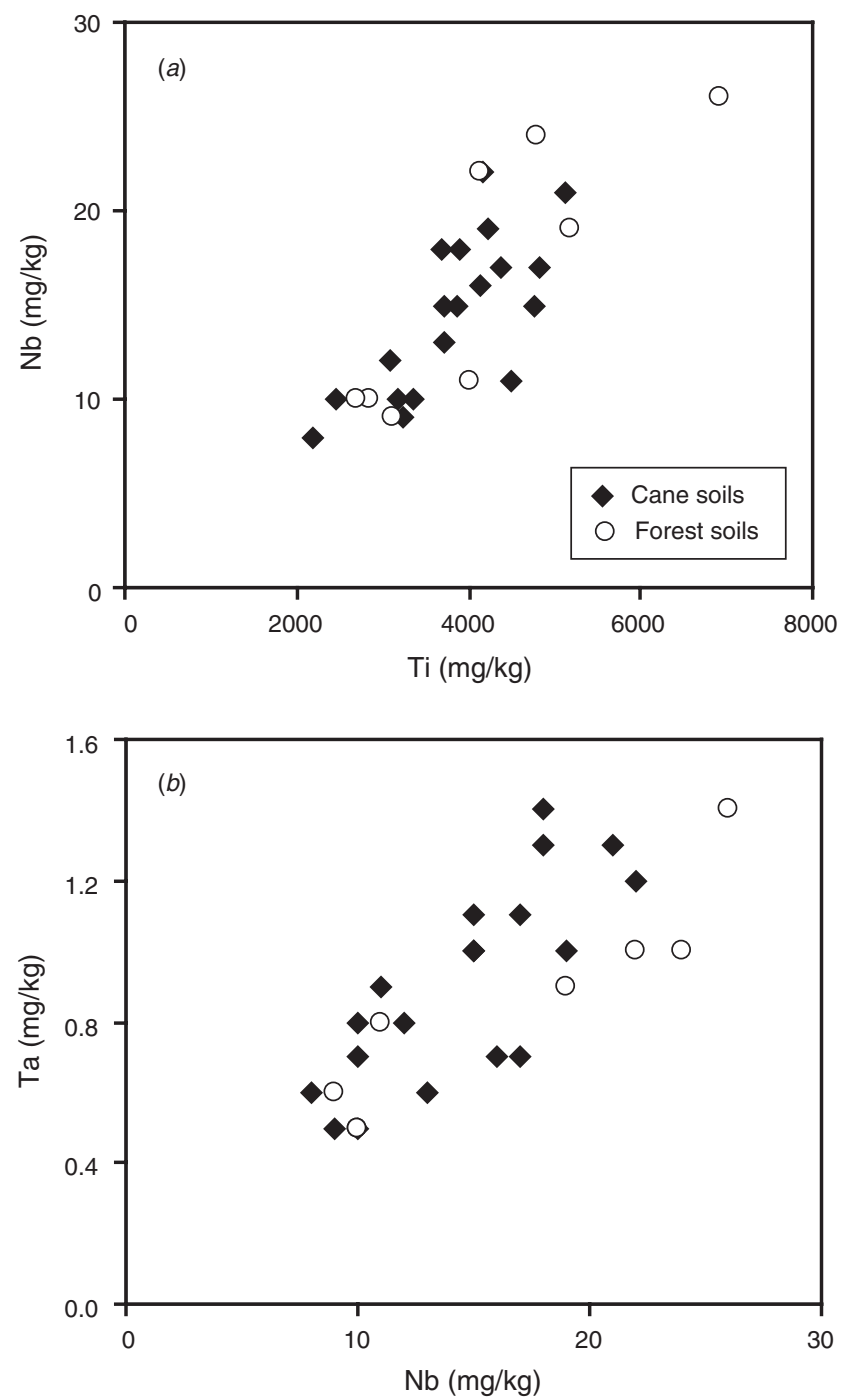

Fig. 2. Bivariate plots of element concentrations for cane and forest soils: (a) Ti $v$. $\mathrm{Nb},(b) \mathrm{Nb} v$. Ta. Both soil types possess a restricted, yet similar, range of $\mathrm{Nb} / \mathrm{Ti}$ and $\mathrm{Ta} / \mathrm{Nb}$ ratios, demonstrating that the elements are immobile. 

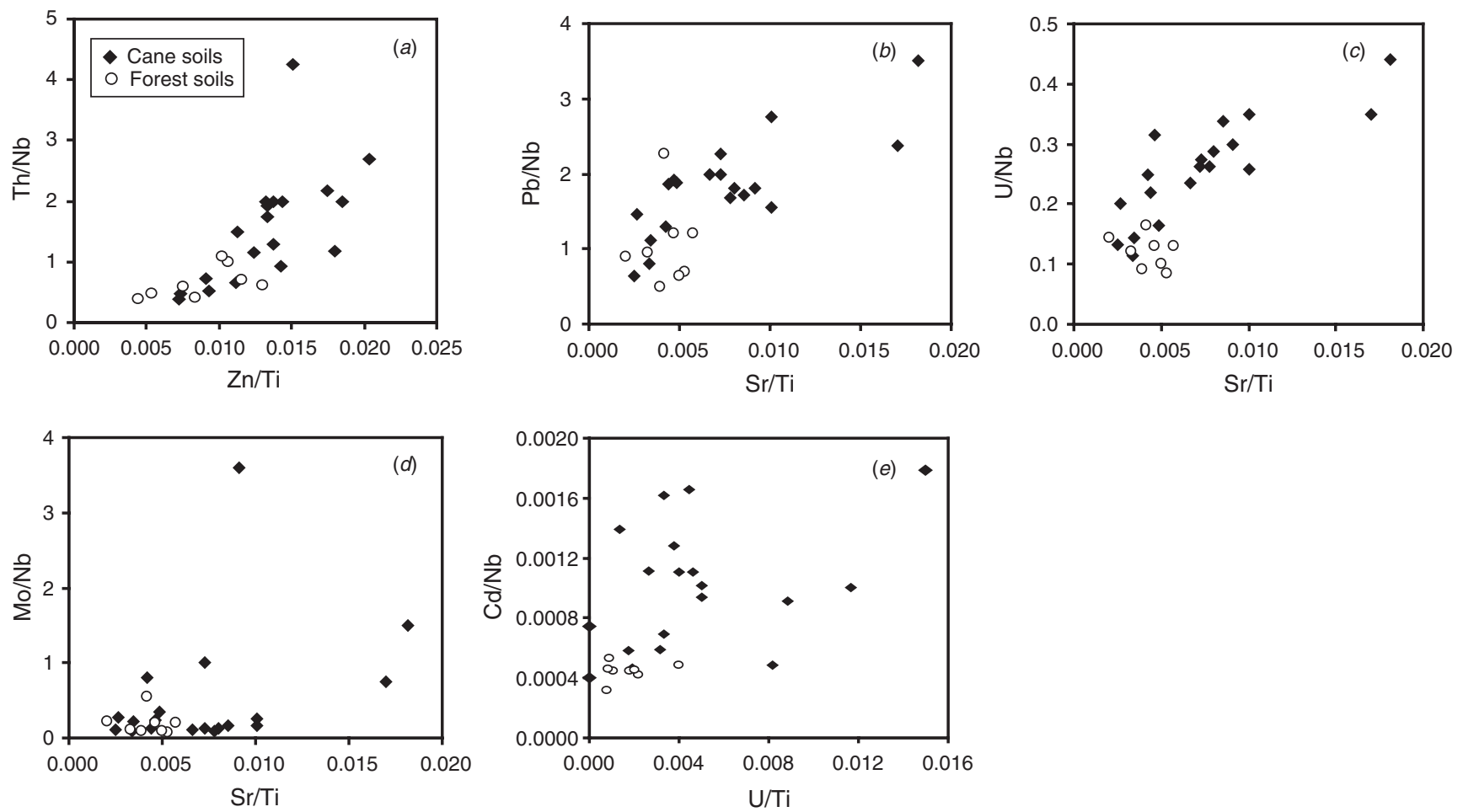

Fig. 3. Bivariate plots of element ratios for cane and forest soils: (a) $\mathrm{Zn} / \mathrm{Ti} v$. Th/Nb, (b) $\mathrm{Sr} / \mathrm{Ti} v$. $\mathrm{Pb} / \mathrm{Nb},(c) \mathrm{Sr} / \mathrm{Ti} v$. U/Nb, (d) $\mathrm{Sr} / \mathrm{Ti} v$. Mo/Nb, (e) $\mathrm{Cd} / \mathrm{Nb} v$. $\mathrm{U} / \mathrm{Ti}$. Cane soils tend to possess higher element ratios than forest soils, illustrating the enrichment of $\mathrm{Cd}, \mathrm{Mo}, \mathrm{Pb}, \mathrm{Sr}$, Th, $\mathrm{U}$, and $\mathrm{Zn}$ concentrations in cane soils.

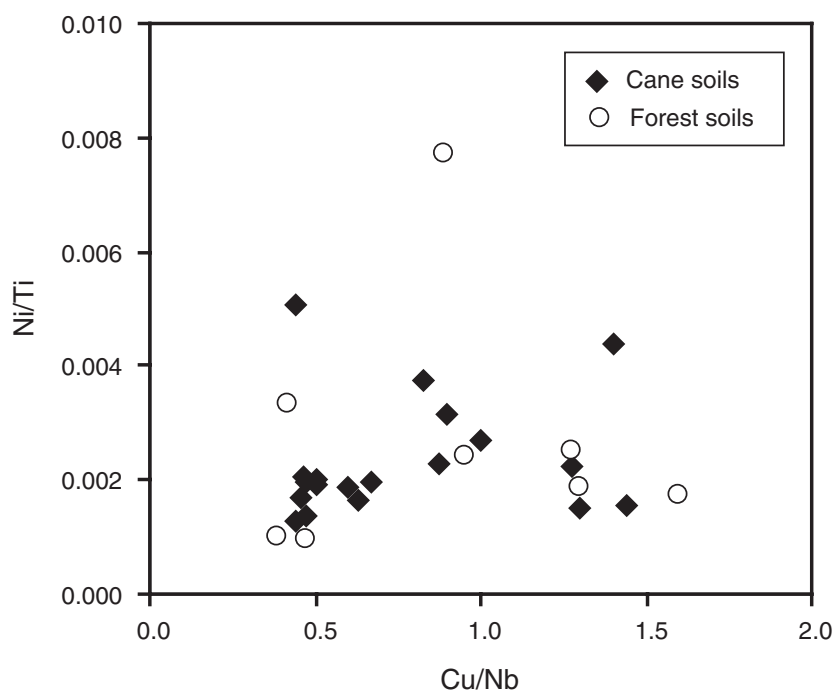

Fig. 4. Bivariate plot of $\mathrm{Cu} / \mathrm{Nb} v$. Ni/Ti for cane and forest soils.

in the cane soils relative to the forest soils unaffected by agricultural activities.

\section{Isotope chemistry of soils}

Isotope analyses of $\mathrm{Pb}, \mathrm{Sr}$, and $\mathrm{U}$ reveal that the cane and forest soils possess distinct ${ }^{207} \mathrm{~Pb} /{ }^{206} \mathrm{~Pb},{ }^{208} \mathrm{~Pb} /{ }^{206} \mathrm{~Pb},{ }^{87} \mathrm{Sr} /{ }^{86} \mathrm{Sr}$, and ${ }^{234} \mathrm{U} /{ }^{238} \mathrm{U}$ ratios (Table 2 ). The 2 soil types display slightly different ${ }^{207} \mathrm{~Pb} /{ }^{206} \mathrm{~Pb},{ }^{208} \mathrm{~Pb} /{ }^{206} \mathrm{~Pb},{ }^{87} \mathrm{Sr} /{ }^{86} \mathrm{Sr}$, and ${ }^{234} \mathrm{U} /{ }^{238} \mathrm{U}$ ratios (Table 2; Fig. 5a). Several trends have been recognised within the data: (1) background forest soils have the highest and least radiogenic ${ }^{207} \mathrm{~Pb} /{ }^{206} \mathrm{~Pb},{ }^{208} \mathrm{~Pb} /{ }^{206} \mathrm{~Pb},{ }^{87} \mathrm{Sr} /{ }^{86} \mathrm{Sr}$, and ${ }^{234} \mathrm{U} /{ }^{238} \mathrm{U}$ ratios (Table 2, Fig. 5 b); (2) cane soils tend to have slightly lower $\mathrm{Sr}$ and $\mathrm{Pb}$ isotope ratios than the background soils, with their ratios trending towards the more radiogenic ratios of phosphate fertilisers (i.e. lower in ${ }^{87} \mathrm{Sr} /{ }^{86} \mathrm{Sr},{ }^{207} \mathrm{~Pb} /{ }^{206} \mathrm{~Pb}$, and ${ }^{208} \mathrm{~Pb} /{ }^{206} \mathrm{~Pb}$ ratios) (Table 2, Fig. 5 b); and (3) the ${ }^{234} \mathrm{U} /{ }^{238} \mathrm{U}$ ratios of cane soils are slightly higher than those of the background soils and identical to those of phosphate fertilisers (Table 1). However, the $\mathrm{Pb}$ isotopic ratios in $1 \mathrm{M}$ $\mathrm{HCl}$ extracts of cane soils do not relate $(r-0.64)$ significantly to their total elemental $\mathrm{Pb}$ concentrations (Fig. 6). That is, the total $\mathrm{Pb}$ concentrations of cane soils only very slightly increase with decreasing $\mathrm{Pb}$ isotope ratios, trending towards the more radiogenic ratios of phosphate fertilisers. Such a minor shift in $\mathrm{Pb}$ isotope composition with $\mathrm{Pb}$ concentration suggests that fertiliser application has only a small impact on $\mathrm{Pb}$ soil chemistry.

\section{Discussion}

\section{Origin of soil chemistry}

The metal content of a soil is a function of natural geochemical concentrations and addition of elements or compounds originating from anthropogenic activities. Concentrations of $\mathrm{Cd}, \mathrm{Cu}, \mathrm{Mo}, \mathrm{Ni}, \mathrm{Pb}, \mathrm{Sr}, \mathrm{Th}, \mathrm{U}$, and $\mathrm{Zn}$ for soils have been stated as 1, 2-100, 2, 5-500, 2-200, 50-1000, 13, 1, and $10-300 \mathrm{mg} / \mathrm{kg}$, respectively (Berkman 1976). Inevitably, most 


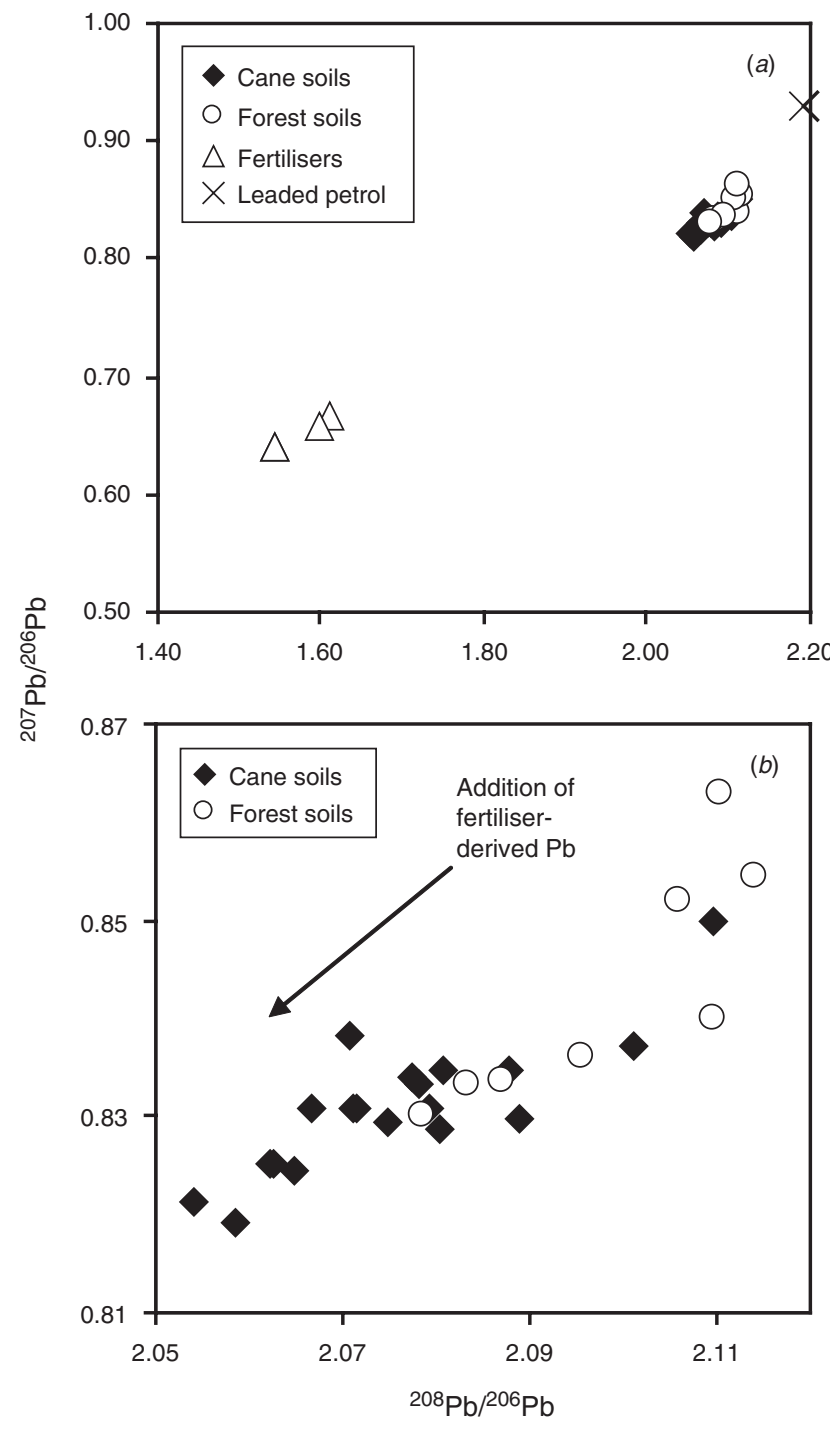

Fig. 5. Lead isotope ratios for $1 \mathrm{M} \mathrm{HCl}$ soil extracts. (a) Relationship between ${ }^{207} \mathrm{~Pb} /{ }^{206} \mathrm{~Pb}$ and ${ }^{208} \mathrm{~Pb} /{ }^{206} \mathrm{~Pb}$ ratios for fertiliser and soil samples from the Saltwater Creek catchment. The $\mathrm{Pb}$ isotope composition of leaded fuel is also shown (Gulson et al. 1994). (b) Enlarged portion of Fig. 5a, showing that the cane soils tend to have lower ${ }^{207} \mathrm{~Pb} /{ }^{206} \mathrm{~Pb}$ and ${ }^{208} \mathrm{~Pb} /{ }^{206} \mathrm{~Pb}$ ratios than the forest soils due to the addition of fertiliser-derived $\mathrm{Pb}$.

soil geochemical surveys include sites affected by atmospheric inputs (e.g. short-range and long-range atmospheric deposition of aerosols originating from waste incinerators, car exhausts, smelters, bushfires) or agricultural amendments (e.g. sewage sludges). Pristine background concentrations would be lower. In this study, the detected average $\mathrm{Cu}, \mathrm{Ni}, \mathrm{Pb}$, and $\mathrm{Zn}$ values in the studied forest soils $(12.2,9.89,16$, and $35.1 \mathrm{mg} / \mathrm{kg}$, respectively; Table 2) are similar to those of topsoils unaffected by agricultural activities and taken from National Park, State Forest, and bushland in southern Queensland (16, 6, 14, and $21 \mathrm{mg} / \mathrm{kg}$, respectively) (Olszowy et al. 1995).

Elevated $\mathrm{Cd}$ and $\mathrm{Hg}$ values have been detected in cane soils of central and southern Queensland (Rayment et al. 1997). Such element enrichments have been assigned to the use of phosphate

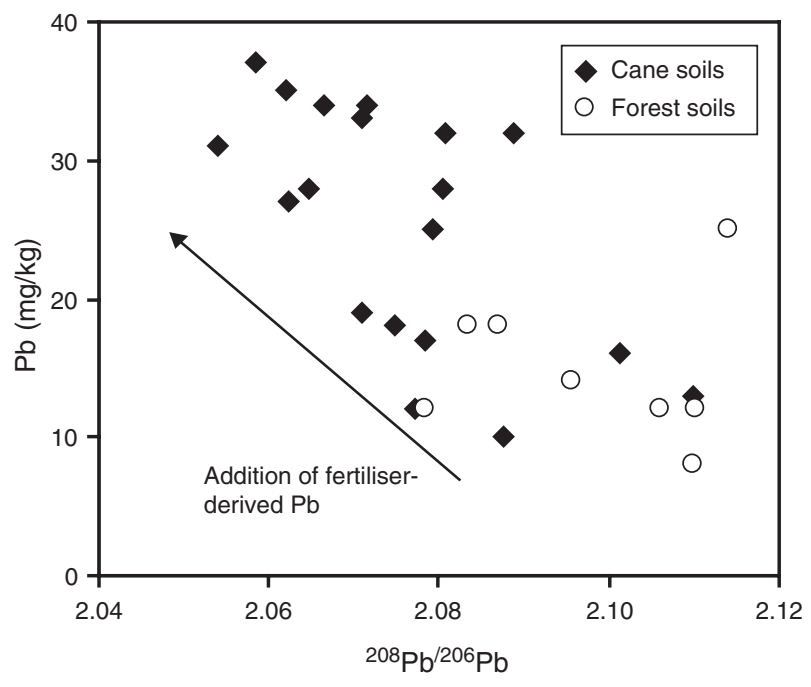

Fig. 6. ${ }^{208} \mathrm{~Pb} /{ }^{206} \mathrm{~Pb}$ for $1 \mathrm{M} \mathrm{HCl}$ soil extracts $v$. total $\mathrm{Pb}$ in cane and forest soils. Cane soils tend to possess higher total $\mathrm{Pb}$ and lower ${ }^{208} \mathrm{~Pb} /{ }^{206} \mathrm{~Pb}$ ratios than the forest soils, caused by the admixing of fertiliser-derived $\mathrm{Pb}$ to cane soils.

fertilisers and $\mathrm{Hg}$ fungicides. Yet, the $\mathrm{Cd}, \mathrm{Pb}$, and $\mathrm{Zn}$ concentrations for cane soils of northern New South Wales were similar to or even lower than those in non-cane soils (Rayment et al. 1998). Thus, the use of metal concentration data on their own did not allow the recognition of anthropogenic-derived metals in cane soils.

Analyses of topsoil samples from canelands by this study have revealed $\mathrm{Cd}, \mathrm{Cu}, \mathrm{Mo}, \mathrm{Ni}, \mathrm{Pb}, \mathrm{Sr}, \mathrm{Th}, \mathrm{U}$, and $\mathrm{Zn}$ concentrations that fall into established background concentrations of soils (Berkman 1976; Olszowy et al. 1995) and soil quality guidelines (ANZECC and NH\&MRC 1992). However, the mean total $\mathrm{Cd}, \mathrm{Mo}, \mathrm{Pb}, \mathrm{Sr}, \mathrm{Th}, \mathrm{U}$, and $\mathrm{Zn}$ concentration plus 1 standard deviation and the median $\mathrm{Cd}$, $\mathrm{Mo}, \mathrm{Pb}, \mathrm{Sr}, \mathrm{Th}, \mathrm{U}$, and $\mathrm{Zn}$ value of cane soils in the Saltwater Creek catchment exceed those of background soils (Table 2). More importantly, the cane soils have acquired higher $\mathrm{Cd} / \mathrm{Nb}, \mathrm{Mo} / \mathrm{Nb}, \mathrm{Pb} / \mathrm{Nb}, \mathrm{Sr} / \mathrm{Ti}, \mathrm{Th} / \mathrm{Nb}, \mathrm{U} / \mathrm{Nb}, \mathrm{U} / \mathrm{Ti}$, and $\mathrm{Zn} / \mathrm{Ti}$ ratios than the background soils. This implies that the cane soils have obtained their $\mathrm{Cd}, \mathrm{Mo}, \mathrm{Pb}, \mathrm{Sr}, \mathrm{Th}, \mathrm{U}$, and $\mathrm{Zn}$ concentrations from geological bedrock as well as other sources (i.e. atmospheric fall-out of traffic-derived $\mathrm{Pb}$, fertiliser, or mechanised equipment during cultivation and harvesting). In this study, road runoff waters, coal ash, dust from mining and smelting activities, and sewage sludge do not represent possible trace metal sources. Soil samples were collected well away from road structures, there are no coal combustion or mining and smelting activities in the regional area, and sewage sludge is not applied to the agricultural land.

\section{Origin of soil isotope chemistry}

The use of $\mathrm{Pb}$ isotope data can also resolve ambiguities where natural and anthropogenic sources of $\mathrm{Pb}$ cannot be easily distinguished solely on the basis of concentration data. The technique is based on the fact that 3 of the 4 lead isotopes $\left({ }^{206} \mathrm{~Pb},{ }^{207} \mathrm{~Pb},{ }^{208} \mathrm{~Pb}\right)$ are radiogenic and have increased in 
abundance with time compared to the non-radiogenic isotope ${ }^{204} \mathrm{~Pb}$. The relative increase for each radiogenic isotope is a function of the decay rate of their radioactive parent isotopes ${ }^{238} \mathrm{U},{ }^{235} \mathrm{U}$, and ${ }^{232} \mathrm{Th}$, respectively. In a closed system, the $\mathrm{Pb}$ isotope composition of a given sample depends on its age and $\mathrm{U} / \mathrm{Pb}$ and $\mathrm{Th} / \mathrm{Pb}$ ratios of the parent materials from which the $\mathrm{Pb}$ was derived (Gulson 1986). If there are additional anthropogenic inputs of $\mathrm{Pb}$ (e.g. atmospheric deposition) into the environment, this input commonly causes differences in $\mathrm{Pb}$ isotopic ratios in soils, sediments, and waters. Hence, variations in the $\mathrm{Pb}$ isotope ratios, such as ${ }^{207} \mathrm{~Pb} /{ }^{206} \mathrm{~Pb}$ and ${ }^{208} \mathrm{~Pb} /{ }^{206} \mathrm{~Pb}$, are commonly used as tracers of environmental contamination processes and as an indicator to differentiate the sources of $\mathrm{Pb}$ in environmental samples (Gulson et al. 1981, 1994, 1995).

Numerous $\mathrm{Pb}$ isotope studies have shown that anthropogenic activities including long- and short-range atmospheric transport and subsequent deposition of anthropogenic aerosols (e.g. from waste incinerators, smelter emissions, and vehicle exhausts) or direct application of waste (e.g. sewage sludge) to agricultural land can lead to $\mathrm{Pb}$ contamination of soils (e.g. Hansmann and Köppel 2000; Shotyk et al. 2003, 2005; Bacon and Hewitt 2005; Steinnes et al. 2005). However, sewage sludges are not applied to the caneland, and possible anthropogenic sources such as smelter stacks, metal refining plants, coal-fired power stations, and waste incinerators are absent in the local and regional area in a $\sim 500 \mathrm{~km}$ radius.

Leaded petrol in Australia and road sediments from the Cairns region have distinctly less radiogenic ${ }^{207} \mathrm{~Pb} /{ }^{206} \mathrm{~Pb}$ ( $\sim 0.93$ and $0.916-0.937$, respectively) and ${ }^{208} \mathrm{~Pb} /{ }^{206} \mathrm{~Pb}(\sim 2.19$ and 2.08-2.11, respectively) ratios than the background forest soils (cf. Gulson et al. 1994; Pratt and Lottermoser 2007) (Fig. 5a). The addition of such traffic-derived $\mathrm{Pb}$ to cane soils would have resulted in less radiogenic ${ }^{207} \mathrm{~Pb} /{ }^{206} \mathrm{~Pb}$ and ${ }^{208} \mathrm{~Pb} /{ }^{206} \mathrm{~Pb}$ ratios and a shift in isotope compositions towards leaded petrol (Fig. 5a). By contrast, the results of the soil survey have indicated a shift in the opposite direction towards slightly more radiogenic ${ }^{207} \mathrm{~Pb} /{ }^{206} \mathrm{~Pb}$ and ${ }^{208} \mathrm{~Pb} /{ }^{206} \mathrm{~Pb}$ ratios in cane soils compared with background soils. The cane topsoils exhibit a $\mathrm{Pb}$ isotope composition that appears on a mixing line between the isotopically distinct background soils and phosphate fertilisers (Fig. 5a,b). The detected shift in $\mathrm{Pb}$ isotope characteristics away from leaded petrol and towards fertiliser compositions can only be accounted for by the addition of fertiliser to cane soils. Yet, the addition of petrol-derived $\mathrm{Pb}$ via long- and short-range atmospheric transport and subsequent deposition of aerosols to both cane and forest soils cannot be excluded. Such an input would impact on the isotope composition of both soil types, cane and forest soils, and hence, both soil types may contain petrolderived $\mathrm{Pb}$.

Mixing calculations of isotope ratios allow the modelling of element sources. Assuming that the applied $1 \mathrm{M} \mathrm{HCl}$ extraction releases all soluble $\mathrm{Pb}$ and that fertilisers are the sole anthropogenic source of $\mathrm{Pb}$ in the cane soils, then the fertilisers provide only $\sim 5 \%$ of the total $\mathrm{Pb}$ in the cane soils. Such minor addition of $\mathrm{Pb}$ is also supported by the fact that the shift in isotope signatures is small (Fig. $2 a, b$ ), and that the mean $\mathrm{Pb}$ concentration plus 1 standard deviation for forest soils $(14.9 \pm 5.2 \mathrm{mg} / \mathrm{kg})$ is only slightly different to that of cane soils $(25.7 \pm 8.7 \mathrm{mg} / \mathrm{kg}$ ) (Table 2$)$.
Strontium isotopes have largely been used as tracers to establish the sources and fluxes of base cations in soil, water, and plant materials (e.g. Capo et al. 1998). By comparison, the use of $\mathrm{Sr}$ isotope ratios to track contamination processes on agricultural land has only been pursued to a limited extent (Martin and McCulloch 1999; Hosono et al. 2007). These authors measured the ${ }^{87} \mathrm{Sr} /{ }^{86} \mathrm{Sr}$ isotope ratios of sediments, soils, and waters from agricultural catchments. The detected $\mathrm{Sr}$ isotope changes in samples from cultivated land were interpreted as being due to the application of phosphate fertilisers. Similarly in this study, the limited $\mathrm{Sr}$ isotope analyses suggest that the cane soils of the Saltwater Creek catchment possess ${ }^{87} \mathrm{Sr} /{ }^{86} \mathrm{Sr}$ isotope ratios that are between background soils and phosphate fertilisers (Tables 1, 2). Hence, the observed changes in elemental and isotopic $\mathrm{Sr}$ compositions in the investigated cane topsoils are inferred to reflect the addition of fertiliser-derived $\mathrm{Sr}$.

Long-term application of U-bearing fertilisers can elevate the U concentration in fertilised soils (Rothbaum et al. 1979; De Kok and Schnug 2008). In this study, the mean U concentration for forest soils $(1.83 \mathrm{mg} / \mathrm{kg}$; Table 2$)$ is half than that of cane soils $(3.7 \mathrm{mg} / \mathrm{kg}$; Table 2$)$. The data suggest that a significant proportion of the $U$ in the cane soils is fertiliser-derived. Fertiliser-derived $U$ can be recognised using $U$ isotope investigations (Zielinski et al. 1997, 2000; Conceição and Bonotto 2003). When rock weathers, ${ }^{234} U$ is preferentially mobilised to ${ }^{238} \mathrm{U}$ (Ivanovich and Harmon 1992). Consequently, soils that have undergone recent weathering display ${ }^{234} \mathrm{U} /{ }^{238} \mathrm{U}$ activity ratios $<1$. The mean ${ }^{234} \mathrm{U} /{ }^{238} \mathrm{U}$ ratio of forest soils of the Saltwater Creek catchment corresponded to 0.92 , which is a typical value for rocks and soils that have been subjected to recent weathering (Conceição and Bonotto 2003). By contrast, the ${ }^{234} U /{ }^{238} U$ activity ratio of cane soils is near unity and identical to that of phosphate fertilisers (Tables 1, 2; Zielinski et al. 1997, 2000; Conceição and Bonotto 2003). Therefore, the limited $U$ isotope analyses suggest that there has been fertiliser-derived input of isotopes ${ }^{234} \mathrm{U}$ and ${ }^{238} \mathrm{U}$ to cane soils. Cane soils of the Saltwater Creek catchment have been enriched in fertiliser-derived $U$.

The investigated forest and cane soils display distinct variations in trace metal contents. These variations cannot be explained by the presence of several different soil types in the catchment. The range of immobile element ratios are restricted in cane and forest soils, demonstrating that both soil sample types derive from the same geological bedrock (i.e. metamorphic rocks). Natural variability in soil chemistry may account for some of the detected elemental variations. However, the $\mathrm{Pb}, \mathrm{Sr}$, and $\mathrm{U}$ isotopic compositions of soils and fertilisers show that varying proportions of trace metals in cane soils are fertiliserderived. The $\mathrm{Pb}$ isotope data indicate only a minor addition of $\mathrm{Pb}$ to agricultural land, whereas the $\mathrm{U}$ data imply that much of the $U$ in cane soils is fertiliser-derived. The presence of higher proportions of fertiliser-derived $U$ in cane soils likely reflects the fact that phosphate fertilisers used in north Queensland have much higher $\mathrm{U}$ than $\mathrm{Pb}$ concentrations (Table 1).

\section{Fate of fertiliser-derived metals}

Erosion and leaching of cultivated land potentially led to the transport of fertiliser-derived trace elements into underlying 
aquifers or even receiving waterways and the coastal zone, as evidenced for fertiliser-derived $\mathrm{Sr}$ and U (cf. Spalding and Sackett 1972; Zielinski et al. 1997, 2000; Martin and McCulloch 1999; Conceição and Bonotto 2003; Hosono et al. 2007). Thus, agricultural soils and nearby land and water resources are becoming increasingly contaminated by metals due to fertiliser use. Fertiliser-derived trace metals appear to enter terrestrial run-off and they can be tracked using isotope and trace element geochemistry.

This study confirms the presence of fertiliser-derived metals ( $\mathrm{Cd}, \mathrm{Mo}, \mathrm{Pb}, \mathrm{Sr}, \mathrm{Th}, \mathrm{U}, \mathrm{Zn}$ ) within soils of the Saltwater Creek catchment, which feeds into the Great Barrier Reef (GBR) lagoon. Since European settlement, there has been an increase in nutrients and sediments flowing into river catchments and wetland ecosystems that discharge into the GBR lagoon (e.g. Neil et al. 2002; McCulloch et al. 2003; Devlin and Brodie 2005). The most significant source of diffuse pollution entering the GBR lagoon is overuse/misuse of fertilisers by cropping industries (Reef Water Quality Protection Plan 2003). Further research on the fate and transport of fertiliser-derived metals from topsoils into aquifers, crops, streams, and estuaries of GBR catchments is recommended.

\section{Acknowledgments}

Dr J. Armour (Qld NRW) is thanked for providing several of the fertiliser samples for analysis. Support for this project was given by James Cook University and the Australian Institute of Nuclear Science and Engineering (grant 05/103). An anonymous reviewer is thanked for a cogent review of the manuscript.

\section{References}

ANZECC (Australian and New Zealand Environment and Conservation Council) (2000) Australian and New Zealand Guidelines for Fresh and Marine Water Quality, Vol. 1. Australian and New Zealand Environment and Conservation Council and Agriculture and Resources Management Council of Australia and New Zealand, pp. 3.5-7.

ANZECC (Australian and New Zealand Environment and Conservation Council) and NH\&MRC (National Health and Medical Research Council) (1992) Australian and New Zealand Guidelines for the Assessment and Management of Contaminated Sites. pp. 38-41.

Bacon JR, Hewitt IJ (2005) Heavy metals deposited from the atmosphere on upland Scottish soils: Chemical and lead isotope studies of the association of metals with soil components. Geochimica et Cosmochimica Acta 69, 19-33. doi: 10.1016/j.gca.2004.06.030

Berkman DA (1976) 'Field geologists' manual.' Monograph No. 9. (Australasian Institute of Mining and Metallurgy: Melbourne, Vic.)

Bultitude RJ, Rees ID, Garrad PD, Champion DC, Fanning CM (1996) 'Mossman Queensland 1:250000 geological series - explanatory notes.' 2nd edn, sheet SE55-1. (Department of Mines \& Energy, Geological Survey: Brisbane, Qld)

Bureau of Meteorology (2008) Climate averages for Port Douglas, Queensland. Available at: www.bom.gov.au/climate/averages/tables/ cw_0310 52.shtml

Buurman P, Rodeja EG, Cortizas AM, van Doesburg JDJ (2004) Stratification of parent material in European volcanic and related soils studied by laser-diffraction grain-sizing and chemical analysis. Catena 56, 127-144. doi: 10.1016/j.catena.2003.10.007

Capo RC, Stewart BW, Chadwick OA (1998) Strontium isotopes as tracers of ecosystem processes: theory and methods. Geoderma 82, 197-225. doi: 10.1016/S0016-7061(97)00102-X
Conceição FT, Bonotto DM (2003) Use of U-isotope disequilibrium to evaluate the weathering rate and fertiliser-derived uranium in Sao Paulo state, Brazil. Environmental Geology 44, 408-418. doi: 10.1007/s00254003-0775-4

De Kok LJ, Schnug E (Eds) (2008) 'Loads and fate of fertilizer-derived uranium.' (Backhuys Publishers: Leiden)

Devlin MJ, Brodie J (2005) Terrestrial discharge into the Great Barrier Reef Lagoon: nutrient behaviour in coastal waters. Marine Pollution Bulletin 51, 9-22. doi: 10.1016/j.marpolbul.2004.10.037

Gulson BL (1986) 'Lead isotopes in mineral exploration. Developments in Economic Geology 23.' (Elsevier: Amsterdam)

Gulson BL, Davis JJ, Mizon KJ, Korsch MJ, Bawden-Smith J (1995) Sources of lead in soil and dust and the use of dust fallout as a sampling medium. The Science of the Total Environment 166, 245-262. doi: 10.1016/0048-9697(95)04505-U

Gulson BL, Mizon KL, Law AJ, Korsch MJ, Davis JJ, Howarth D (1994) Source and pathways of lead in humans from the Broken Hill mining community; an alternative use of exploration methods. Economic Geology and the Bulletin of the Society of Economic Geologists 89, 889-908.

Gulson BL, Tiller KG, Mizon KJ, Merry RH (1981) Use of lead isotopes in soils to identify the source of lead contamination near Adelaide, South Australia. Environmental Science \& Technology 15, 691-696. doi: 10.1021/es00088a008

Hansmann W, Köppel V (2000) Lead-isotopes as tracers of pollutants in soils. Chemical Geology 171, 123-144. doi: 10.1016/S0009-2541(00) 00230-8

Hart SR, Coetzee M, Workman RK, Blusztajn J, Johnson KTM, Sinton JM, Steinberger B, Hawkins JW (2004) Genesis of the Western Samoa seamount province: age, geochemical fingerprint and tectonics. Earth and Planetary Science Letters 227, 37-56. doi: 10.1016/ j.eps1.2004.08.005

Hosono T, Nakano T, Igeta A, Tayasu I, Tanaka T, Yachi S (2007) Impact of fertilizer on a small watershed of Lake Biwa: use of sulphur and strontium isotopes in environmental diagnosis. The Science of the Total Environment 384, 342-354. doi: 10.1016/j.scitotenv.2007.05.033

Ivanovich M, Harmon RS (1992) 'Uranium series disequilibrium: applications to environmental problems.' 2nd edn (Oxford University Press: Oxford, UK)

Kurtz AC, Derry LA, Chadwick OA, Alfano MJ (2000) Refractory element mobility in volcanic soils. Geology 28, 683-686. doi: 10.1130/00917613(2000)28<683:REMIVS >2.0.CO;2

Martin CE, McCulloch MT (1999) Nd-Sr isotopic and trace element geochemistry of river sediments and soils in a fertilized catchment, New South Wales, Australia. Geochimica et Cosmochimica Acta 63, 287-305. doi: 10.1016/S0016-7037(98)00308-1

McBride MB, Spiers G (2001) Trace element content of selected fertilizers and diary manures as determined by ICP-MS. Communications in Soil Science and Plant Analysis 32, 139-156. doi: 10.1081/CSS-100102999

McCulloch M, Pailles C, Moody P, Martin CE (2003) Tracing the source of sediment and phosphorus into the Great Barrier Reef lagoon. Earth and Planetary Science Letters 210, 249-258. doi: 10.1016/S0012-821X(03) 00145-6

McLaughlin MJ, Hamon RE, McLaren RG, Speir TW, Rogers SL (2000) Review: a bioavailability-based rationale for controlling metal and metalloid contamination of agricultural land in Australia and New Zealand. Australian Journal of Soil Research 38, 1037-1086. doi: $10.1071 /$ SR99128

Meijer EL, Buurman P (2003) Chemical trends in a perhumid soil catena on the Turrialba volcano (Costa Rica). Geoderma 117, 185-201. doi: 10.1016/S0016-7061(03)00122-8

Molloy R, McLaughlin M, Warne M, Hamon R, Kookana R, Saison C (2005) Background and scope for establishing a list of prohibited substances and guideline limits for levels of contaminants in fertilizers. CSIRO Land \& Water, Technical Report. 
Murtha GG (1989) Soils of the Mossman Cape Tribulation area, north Queensland. CSIRO Division of Soils Divisional Report No. 102.

Neil DT, Orpin AR, Ridd PV, Yu B (2002) Sediment yield and impacts from river catchments to the Great Barrier Reef Lagoon. Marine and Freshwater Research 53, 733-752. doi: 10.1071/MF00151

Nriagu JO, Pacyna JM (1988) Quantitative assessment of worldwide contamination of air, water and soils by trace metals. Nature 333, 134-139. doi: $10.1038 / 333134 a 0$

Olszowy H, Imray P, Torr P (1995) Trace element concentrations in soils from rural and urban areas of Australia. Contaminated Sites Monograph No. 4. (South Australian Health Commission: Adelaide, S. Aust.)

Pratt C, Lottermoser BG (2007) Mobilisation of traffic-derived trace metals from road corridors into coastal stream and estuarine sediments, Cairns, north Queensland, Australia. Environmental Geology 52, 437-448. doi: $10.1007 / \mathrm{s} 00254-006-0471-2$

Pulsford JS (1993) 'Historical nutrient usage in coastal Queensland river catchments adjacent to the Great Barrier Reef Marine Park.' Research Publication No. 40. (Great Barrier Reef Marine Park Authority: Townsville, Qld)

Raven KP, Loeppert RH (1997) Trace element composition of fertilizers and soil amendments. Journal of Environmental Quality 26, 551-557.

Rayment GE, Jeffrey AJ, Barry GA (1998) Heavy metals in New South Wales canelands. Proceedings of Australian Society of Sugar Cane Technologists 20, 63-68.

Rayment GE, Jeffrey AJ, Barry GA, Chapman L (1997) Heavy metals in southern and central Queensland canelands. Proceedings of Australian Society of Sugar Cane Technologists 19, 208-212.

Reef Water Quality Protection Plan (2003) Reef Water Quality Protection Plan: for Catchments Adjacent to the Great Barrier Reef World Heritage Area. Queensland State Government \& Environment Australia.

Rothbaum HP, McGaveston DA, Wall T, Johnston AE, Mattingly GEG (1979) Uranium accumulation in soils from long-continued applications of superphosphate. Journal of Soil Science 30, 147-153. doi: 10.1111/ j.1365-2389.1979.tb00972.x

Shotyk W, Goodsite ME, Roos-Barraclough F, Frei R, Heinemeier J, Asmund G, Lohse C, Hansen TS (2003) Anthropogenic contributions to atmospheric $\mathrm{Hg}, \mathrm{Pb}$ and $\mathrm{As}$ accumulation recorded by peat cores from southern Greenland and Denmark dated using the ${ }^{14} \mathrm{C}$ "bomb pulse curve". Geochimica et Cosmochimica Acta 67, 3991-4011. doi: 10.1016/S0016-7037(03)00409-5
Shotyk W, Goodsite ME, Roos-Barraclough F, Givelet N, Le Roux G, et al. (2005) Accumulation rates and predominant atmospheric sources of natural and anthropogenic $\mathrm{Hg}$ and $\mathrm{Pb}$ on the Faroe Islands. Geochimica et Cosmochimica Acta 69, 1-17. doi: 10.1016/ j.gca.2004.06.011

Spalding RF, Sackett WM (1972) Uranium in runoff from the Gulf of Mexico distributive province: anomalous concentrations. Science $\mathbf{1 7 5}$, 629-631. doi: 10.1126/science.175.4022.629

Steinnes E, Sjøbakk TE, Donisa C, Brännvall ML (2005) Quantification of pollutant lead in forest soils. Soil Science of America Journal 69, 1399-1404. doi: 10.2136/sssaj2004.0095

Taylor MD (1997) Accumulation of cadmium derived from fertilizers in New Zealand soils. The Science of the Total Environment 208, 123-126. doi: 10.1016/S0048-9697(97)00273-8

Williams CH, David DJ (1973) The effect of superphosphate on the cadmium content of soils and plants. Australian Journal of Soil Research 11, 43-56. doi: 10.1071/SR9730043

Williams CH, David DJ (1976) The accumulation in soil of cadmium residues from phosphate fertilizers and their effect on the cadmium content of plants. Soil Science 121, 86-93.

Zielinski RA, Asher-Bolinder S, Meier AL, Johnson CA, Szabo BJ (1997) Natural of fertilizer-derived uranium in irrigation drainage: a case study in southeastern Colorado, U.S.A. Applied Geochemistry 12, 9-21. doi: 10.1016/S0883-2927(96)00050-9

Zielinski RA, Simmons KR, Orem WH (2000) Use of ${ }^{234} \mathrm{U}$ and ${ }^{238} \mathrm{U}$ isotopes to identify fertilizer-derived uranium in the Florida Everglades. Applied Geochemistry 15, 369-383. doi: 10.1016/S08832927(99)00053-0

Manuscript received 20 December 2006, accepted 2 December 2008 